\title{
Insights into fish host-parasite trophic relationships revealed by stable isotope analysis
}

\author{
Salud Deudero ${ }^{1,2}$, John K. Pinnegar ${ }^{1,3, *}$, Nicholas V. C. Polunin ${ }^{1}$ \\ ${ }^{1}$ Department of Marine Sciences \& Coastal Management, University of Newcastle, Newcastle upon Tyne NE1 7RU, \\ United Kingdom \\ ${ }^{2}$ Institut Mediterrani d'Estudis Avançats, Miguel Marqués 21, 07190 Esporles, Mallorca, Spain \\ ${ }^{3}$ Centre for Environment, Fisheries \& Aquaculture Science, Lowestoft Laboratory, Pakefield Road, Lowestoft, \\ Suffolk NR33 0HT, United Kingdom
}

\begin{abstract}
Trophic relationships between 10 species of fish host and their associated nematode, cestode, and copepod parasites were investigated using stable isotopes of carbon and nitrogen. Nematodes and cestodes were consistently depleted in ${ }^{15} \mathrm{~N}$ with respect to their host, and such fractionation patterns are unlike those conventionally observed between consumers and their diets. Species of copepod parasite were sometimes depleted and sometimes enriched in ${ }^{15} \mathrm{~N}$ with respect to fish hosts, and this confirms earlier reports that the nature and magnitude of ectoparasite-host fractionations can vary. Significant differences in ${ }^{15} \mathrm{~N}$ and ${ }^{13} \mathrm{C}$ were observed among fish tissues, and the isotopic signature of parasites did not always closely correspond to that of the tissue with which the parasite was found most closely associated, or on which the parasite was thought to be feeding. Several possible explanations are considered for such discrepancies, including selective feeding on specific amino acids or lipids, migration of the parasite among different fish tissues, changes in the metabolism of the parasite associated with life history and migration between different host animals.
\end{abstract}

KEY WORDS: Ectoparasite $\cdot$ Endoparasite $\cdot$ Stable isotope $\cdot$ Fractionation $\cdot$ Carbon $\cdot$ Nitrogen

\section{INTRODUCTION}

Fish are host to a wide variety of parasitic organisms, including more than 1566 species of parasitic copepod, 1390 species of trematode, 594 species of nematode and 859 species of cestode (Yamaguti 1958, 1959, 1961, 1963). Parasites can confer considerable economic losses to both aquaculture and fisheries, and many parasites can be passed to humans through the eating of raw fish (Williams \& Jones 1994, Bush et al. 2001). There are myriad ways in which parasites can influence the population dynamics of the host fish species (Minchella \& Scott 1991), and in recent years there have been repeated calls for the inclusion of parasites in aquatic food-web studies (Huxham \& Raffaelli 1995,

${ }^{*}$ Corresponding author. E-mail: j.k.pinnegar@cefas.co.uk
Marcogliese \& Cone 1997). However, little is known about the trophic relationships which exist between many parasites and their fish hosts generally (Williams \& Jones 1994).

Stable isotope analysis (SIA) provides a means of exploring trophic relationships within food-webs (see Polunin \& Pinnegar 2002). SIA integrates short-term variation in assimilated diet and is thus much less subject to temporal bias than is gut-content analysis (Hesslein et al. 1993). Furthermore, the contribution of certain dietary constituents, such as detritus, gelatinous material or in the case of parasites mucus and blood, which are scarcely discernible in gut contents, may be elucidated by stable isotope studies. Hence, isotopic data can reveal details about foodwebs and feeding relationships that are otherwise undetectable (Pinnegar et al. 2001, Polunin \& Pinnegar 2002). 
With each trophic transfer between a consumer and its diet, stable carbon-isotope ratios $\left({ }^{13} \mathrm{C}\right)$ increase on average by ca. 1\% (DeNiro \& Epstein 1978), whereas stable-nitrogen-isotope ratios $\left({ }^{15} \mathrm{~N}\right)$ increase by ca. $3 \%$ o (Minagawa \& Wada 1984). In aquatic ecology, ${ }^{13} \mathrm{C}$ values have been used most often to distinguish between primary food sources (e.g. macroalgae, seagrasses and phytoplankton), whereas ${ }^{15} \mathrm{~N}$ values have allowed the determination of trophic level (Vander Zanden et al. 1997, Post et al. 2000).

SIA has only recently been utilised to explore hostparasite relationships, and thus far the fractionation patterns that have been revealed have been somewhat equivocal. In some cases parasites have been shown to be enriched in ${ }^{15} \mathrm{~N}$ or ${ }^{13} \mathrm{C}$ with respect to their hosts, as might be expected for a predator feeding on a prey (e.g. Doucett et al. 1999). However, in other studies both enriched and depleted parasites have occurred on the same host (e.g. Boag et al. 1998, Neilson \& Brown 1999). In fish host-parasite systems (Iken et al. 2001, Pinnegar et al. 2001), endoparasites are rarely enriched in ${ }^{15} \mathrm{~N}$ with respect to their host, and this appears to be particularly so for nematodes and cestodes, which are often significantly depleted (Iken et al. 2001, Pinnegar et al. 2001). On the other hand, it would appear that ectoparasites (e.g. copepod, cirriped and isopod crustaceans) can be either enriched or depleted, depending on their feeding strategy and/or life-history stage (Iken et al. 2001, Pinnegar et al. 2001).

The magnitude and direction of the fractionation step between a parasite and its host may actually be part of a continuum, and dependent upon the rate of feeding, the rate of excretion, and the assimilation efficiency or feeding selectivity of the parasite (Olive et al. in press). The implications of this, and the existing evidence from field studies, are that the 3 criteria proposed by Doucett et al. (1999), to judge whether an organism is truly parasitic or phoretic, should not be used. Specifically, (1) parasites are not always isotopically enriched in terms of ${ }^{13} \mathrm{C}$ or ${ }^{15} \mathrm{~N}$ with respect to their host, (2) isotopic differences between parasite and host do not always fall within the range measured for typical diet-consumer systems in the laboratory, and (3) stable isotope measurements taken for individual parasitic organisms do not always correlate well with measurements for their particular host.

The aim of the present study was to use new data to explore: (1) Whether there are consistent or characteristic patterns in the magnitude/direction of the hostparasite fractionation, for particular parasite taxa (e.g. nematodes, cestodes, copepods). (2) Whether there are consistent or characteristic patterns in the magnitude/direction of the host-parasite fractionation, for ectoparasites and endoparasites. (3) Whether parasites collected from different tissues of the same host exhibit consistent or characteristic patterns in the magnitude/direction of the isotopic fractionation step. (4) Whether the isotopic signature of individual parasites correlates with the signature of the specific host from which it was extracted.

\section{MATERIALS AND METHODS}

Ten species of fish host and their associated parasites (Cestoda, Nematoda, Copepoda) were sampled from a variety of freshwater and marine habitats. Roach Rutilus rutilus were sampled at the Alltami Angling Club, Flintshire, Wales, UK (52 $\left.39^{\prime} \mathrm{N}, 3^{\circ} 26^{\prime} \mathrm{W}\right)$ using a $1 \mathrm{~m}$ deep, weighted net. Hake Merluccius merluccius were collected off Palma de Mallorca, Spain (39 30' N, $\left.3^{\circ} 40^{\prime} \mathrm{E}\right)$, using a commercial otter trawl. Sprat Sprattus sprattus, herring Clupea harengus and several whiting Merlangius merlangus were collected from the screens of Hartlepool power-station, NE England (54 $38^{\prime} \mathrm{N}$, $\left.1^{\circ} 11^{\prime} \mathrm{W}\right)$. Flounder Platichthys flesus, cod Gadus morhua and whiting $M$. merlangus were collected using either an otter trawl off the River Tyne, UK $\left(55^{\circ} 8^{\prime} \mathrm{N}, 1^{\circ} 16^{\prime} \mathrm{W}\right)$, or an Agassiz trawl off Filey, Yorkshire, UK $\left(54^{\circ} 14^{\prime} \mathrm{N}, 0^{\circ} 9^{\prime} \mathrm{W}\right)$, deployed from the RV 'Bernicia'. Additional herring C. harengus, grey gurnard Eutrigla gurnardus, haddock Melanogrammus aeglefinus and bluemouth redfish Helicolenus dactylopterus were purchased from market suppliers, having been landed at the fishing port of North Shields.

With the exception of Helicolenus dactyloperus, a minimum of 3 host fish were sampled, and these were carefully dissected and any parasites associated with the skin, gills, liver, peritoneal cavity, gonads or intestinal tract were removed. Because muscle tissue usually represents around $74 \%$ of total fish body mass (Plimmer 1921), and the majority of this consists of white muscle (McLaughlin \& Kramer 1991), dorsal white muscle was used as a proxy for the whole host. In addition, where a parasite had been found associated with a particular tissue (e.g. gill, liver, intestine), samples of this tissue were also collected for analysis. All tissues and individual parasite samples were freeze-dried and ground to a fine homogeneous powder using a mortar and pestle. ${ }^{15} \mathrm{~N},{ }^{14} \mathrm{~N},{ }^{12} \mathrm{C}$ and ${ }^{13} \mathrm{C}$ in the samples were determined using continuous flow isotope ratio mass spectrometry (CF-IRMS) (Preston 1992). Weighed samples of ground material ( $1 \mathrm{mg}$ ) were oxidised and the $\mathrm{N}_{2}$ and $\mathrm{CO}_{2}$ passed to a single inlet duel collector mass spectrometer (PDZ Europa ANCA SL 20-20 system). Isotope ratios were expressed as parts per thousand (\%) differences from a standard reference material: 


$$
\boldsymbol{X}=\frac{R_{\text {sample }}}{R_{\text {standard }}}-1 \quad 10^{3}
$$

where $X$ is ${ }^{15} \mathrm{~N}$ or ${ }^{13} \mathrm{C}$ and $R$ is the corresponding ratio ${ }^{15} \mathrm{~N}:{ }^{14} \mathrm{~N}$ or ${ }^{13} \mathrm{C}:{ }^{12} \mathrm{C}$ and is the measure of heavy to light isotope in the sample. The standard international reference material for carbon is Vienna Pee Dee Belemnite (vPDB) and atmospheric $\mathrm{N}_{2}$ for nitrogen. White muscle tissue of cod Gadus morhua was used as an internal reference material to calibrate the system and compensate for drift over time. Experimental precision (based on the standard deviation of replicates of the internal reference) was $0.077 \%$ for ${ }^{13} \mathrm{C}$ and $0.069 \%$ for ${ }^{15} \mathrm{~N}$. In accordance with the findings of Bunn et al. (1995) and Pinnegar \& Polunin (1999), samples containing inorganic carbonate (the copepods Lernaeocera branchialis, Clavella adunca, Lernaeenicus sprattae and Lepeophtheirus pectoralis) were divided into 2 roughly equal sub-samples with one analysed after acidification with $1 \mathrm{M} \mathrm{HCl}$ and re-drying, for ${ }^{13} \mathrm{C}$ determination, and the other analysed untreated for

${ }^{15} \mathrm{~N}$. Where sample sizes allowed $(\mathrm{n}>3)$ pairwise comparisons were made between the stable isotope data for each host (white muscle tissue) and its respective parasite using Student's $t$-tests $(=0.05)$. To test whether particular parasite taxa (e.g. Nematoda, Copepoda, Cestoda) exhibited consistent and characteristic isotope fractionation patterns across the full range of fish hosts, Wilcoxon matched-pairs tests were applied ( $=0.05$ ) (Zar 1996). Pearson correlation coefficients were calculated to look for ${ }^{13} \mathrm{C}$ and ${ }^{15} \mathrm{~N}$ relationships between individual hosts and their parasites. Nematode parasites were not identified to the species level.

\section{RESULTS}

\section{General trends}

The relationship between parasites and their hosts deviated from those expected of a predator feeding on bulk tissues of its prey. All nematodes $(n=61)$ were depleted in ${ }^{15} \mathrm{~N}$ with respect to their individual host animal (white muscle tissue) (Wilcoxon $T=0, \mathrm{p}<0.001$ ), and in a significant number of cases were also depleted in ${ }^{13} \mathrm{C}$ (Wilcoxon $T=579, \mathrm{p}<0.01$ ). Cestodes (Ligula intestinalis) were generally $(\mathrm{n}=9)$ depleted in ${ }^{15} \mathrm{~N}$ with respect to their hosts (Wilcoxon $T=1, \mathrm{p}=0.01$ ); individuals were sometimes more enriched and sometimes depleted in ${ }^{13} \mathrm{C}$ (Wilcoxon $T=17, \mathrm{p}>0.5$ ). Copepod parasites $(n=21)$ did not exhibit a consistent fractionation pattern in terms of ${ }^{15} \mathrm{~N}$ (Wilcoxon $T=97, \mathrm{p}>0.5$ ), but in a significant number of cases, were depleted in ${ }^{13} \mathrm{C}$ with respect to their hosts (Wilcoxon $T=37, \mathrm{p}=0.005$ ).
In the majority of cases where sample sizes allowed pairwise comparisons to be made (Table 1), nematodes and cestodes were significantly depleted in ${ }^{15} \mathrm{~N}$ with respect to their hosts (white muscle tissue). However, there were apparently no significant differences in

${ }^{15} \mathrm{~N}$ between copepods and their hosts. In terms of

${ }^{13} \mathrm{C}$, there were very few significant differences between parasite and hosts (Table 1), although Clavella adunca was significantly depleted with respect to whiting Merlangius merlangus, and intestinal/liver nematodes were depleted with respect to hake Merluccius merluccius.

Only ${ }^{15} \mathrm{~N}$ values associated with individual Lernaeocera branchialis and their host whiting were significantly correlated (Table 1), i.e. individual hosts exhibiting a high ${ }^{15} \mathrm{~N}$ housed copepods with a high ${ }^{15} \mathrm{~N}$. In terms of ${ }^{13} \mathrm{C}$, significant correlations were observed for individual $L$. branchialis and haddock Melanogrammus aeglefinnus, and L. branchialis, stomach nematodes, peritoneal cavity nematodes and whiting hosts (Table 1).

\section{Differences between fish tissues}

Significant but consistent differences were observed in isotopic signatures among fish tissues (Fig. 1) irrespective of the fish species from which they were dissected. Fish liver was consistently $(n=15)$ depleted in both ${ }^{15} \mathrm{~N}$ and ${ }^{13} \mathrm{C}$ with respect to white muscle tissue from the same animal (Wilcoxon $T=2$ and 0 respectively, $\mathrm{p}<0.001)$. Gill filaments were consistently $(n=6)$ depleted in ${ }^{15} \mathrm{~N}$ but enriched in ${ }^{13} \mathrm{C}$, with respect to white muscle tissue (Wilcoxon $T=0$, p $<0.001$ ). Stomach and blood samples were consistently ( $\mathrm{n}=4$ and 3 respectively) depleted in ${ }^{13} \mathrm{C}$ compared with white muscle tissue (Wilcoxon $T=0, \mathrm{p}<0.001$ ), and intestine $(n=8)$ and testes $(n=3)$ were consistently depleted in ${ }^{15} \mathrm{~N}$ (Wilcoxon $T=0, \mathrm{p}<0.001$ ) with respect to white muscle tissue.

Pairwise comparisons between parasites and the specific tissues from which they were extracted revealed that liver nematodes were significantly depleted in ${ }^{15} \mathrm{~N}$ and enriched in ${ }^{13} \mathrm{C}$ with respect to hake liver tissue ( $\mathrm{p}=0.001$ and $2.61 \quad 10^{-14}$ respectively). Stomach nematodes were significantly enriched in ${ }^{13} \mathrm{C}$ with respect to whiting stomach tissue. However, in whiting, gut nematodes were not significantly different from intestine tissue, liver nematodes did not differ from liver tissue and copepods (Clavella adunca or Lernaeocera branchialis) did not differ significantly from gill tissue in terms of either ${ }^{15} \mathrm{~N}$ or ${ }^{13} \mathrm{C}$.

The isotopic signature of parasites rarely reflected that of the fish tissue from which they were extracted (Fig. 1), particularly if the notion that consumers 


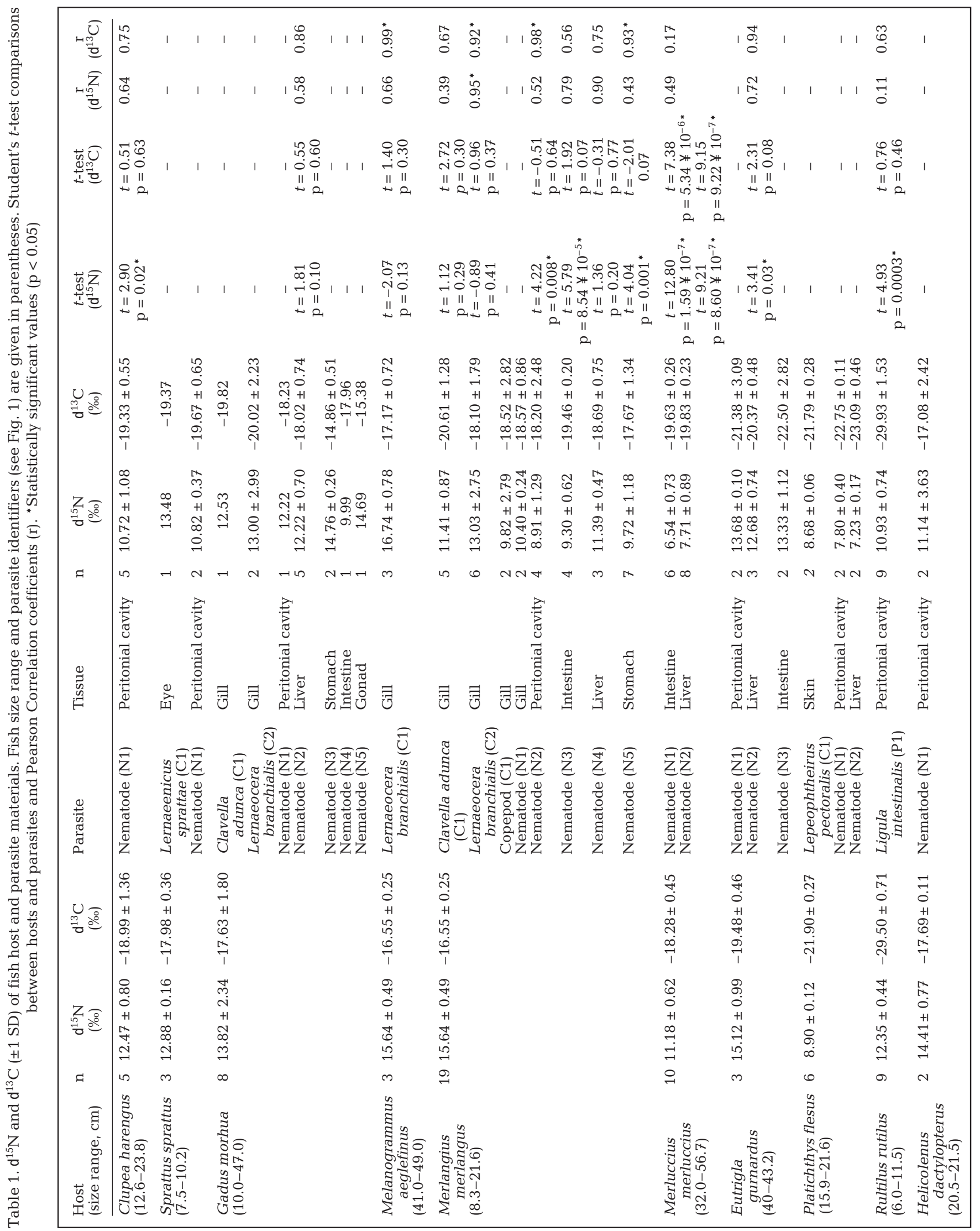


should be enriched in both ${ }^{15} \mathrm{~N}$ and ${ }^{13} \mathrm{C}$ with respect to their diet is considered. Liver nematodes in flounder, gurnard, hake and whiting were always depleted in ${ }^{15} \mathrm{~N}$ with respect to the host's liver, and disproportionately (more than the $1 \%$ expected) enriched in ${ }^{13} \mathrm{C}$. Similarly stomach nematodes were disproportionately enriched in ${ }^{13} \mathrm{C}$ with regard to whiting and gurnard stomachs, and for the gurnard they were greatly depleted in ${ }^{15} \mathrm{~N}$. Gut nematodes were depleted in ${ }^{15} \mathrm{~N}$ with respect to intestine wall tissue (whiting and gurnard), but enriched in ${ }^{13} \mathrm{C}$ for cod and whiting. Parasites of the peritoneal cavity did not seem to reflect the isotopic signature of the host's blood in gurnard and herring. The copepod Lernaeocera branchialis was more enriched in ${ }^{15} \mathrm{~N}$ than gill tissue from the host (cod, whiting and haddock) as one might expect, but for haddock and whiting the parasite was depleted in ${ }^{13} \mathrm{C}$. Clavella adunca, another copepod parasite extracted from the gill of the host, was enriched in both ${ }^{13} \mathrm{C}$ and ${ }^{15} \mathrm{~N}$ with respect to cod gill filament tissue, but very dissimilar to gill tissue in whiting (depleted in both ${ }^{15} \mathrm{~N}$ and ${ }^{13} \mathrm{C}$ ) and the other gill parasite $L$. branchialis.

\section{DISCUSSION}

\section{Nitrogen}

The finding that every single nematode parasite $(\mathrm{n}=$ $61)$ and the majority of cestodes $(n=9)$ were depleted in ${ }^{15} \mathrm{~N}$ with respect to their hosts is in clear disagreement with the enrichment commonly observed between consumers and their diets. This lack of enrichment does however agree with earlier findings for nematode and cestode parasites in fish hosts (Iken et al. 2001, Pinnegar et al. 2001). It is also in accordance with the depletion observed for some rabbit and plant parasites by Boag et al. (1998) and Neilson \& Brown (1999).

${ }^{15} \mathrm{~N}$ trophic enrichment is generally acknowledged to be the result of transamination, i.e. the breakdown of proteins to amino acids, and the consequential loss of isotopically 'light' (rich in ${ }^{14} \mathrm{~N}$ ) excretory products (Macko et al. 1986). It is believed that most parasitic helminths possess only limited capability to biosynthesise amino acids (Köhler \& Voigt 1988). Thus instead of breaking down complex proteins (via transamination), they meet most of their requirements by actively absorbing amino acids directly from the host, i.e. very little de novo synthesis takes place (Howell 1976). Fish blood and body fluids are a rich source of 'free' amino acids (e.g. Wilson \& Poe 1974). Parasitic cestodes, trematodes and many larval nematodes are able to transport amino acids directly across the body surface (tegument) (Rutherford et al. 1977, Barrett 1981). Many of the 'essential' amino acids, acquired by the parasite from the fish host, are typically depleted in ${ }^{15} \mathrm{~N}$ (Hare et al. 1991). The selection of these amino-acids may further contribute to the apparent lack of observed trophic enrichment between endoparasites and hosts. Soutter et al. (1980) found that blood amino-acid levels in $R u$ tilus rutilus infested with the cestode Ligula intestinalis were greatly reduced, and characteristic of fish suffering from starvation. Furthermore, L. intestinalis and Schistocephalus solidus are known to be able to absorb larger macromolecules by endocytosis, for example proteins, as well as amino acids (Köhler \& Voigt 1988).

Some transamination and deamination does occur in endoparasitic helminths and the ammonia arising from these reactions constitutes about $80 \%$ of the total excretory nitrogen (Köhler \& Voigt 1988). However, excesses of substrates and products sometimes result in the formation of complexes which inhibit transamination (Velick \& Vavra 1962). It is also possible that some endoparasites can reutilise the isotopically 'light' excreted ammonia (or that from the hosts blood) for amino acid synthesis via a reversal of the glutamate-dehydrogenase reaction (Barrett 1981), thereby again contributing to a lack of ${ }^{15} \mathrm{~N}$ depletion between endoparasite and host.

The observation that copepod parasites $(n=21)$ did not exhibit a consistent fractionation pattern in terms of ${ }^{15} \mathrm{~N}$ with respect to their fish hosts agrees with earlier findings for ectoparasites. Pinnegar et al. (2001) found that the isopod Anilocra physodes and larvae of the copepod Lernaeocera branchialis did not differ significantly in ${ }^{15} \mathrm{~N}$ with respect to bogue Boops boops and flounder Platichthys flesus. Iken et al. (2001) found that a cirriped parasite did not differ significantly from its decapod host Munidopsis crassa, but that a copepod parasite was greatly enriched with respect to Coryphaenoides armatus. Boag et al. (1998) observed that the flea Spilopsyllus cuniculi was significantly enriched in ${ }^{15} \mathrm{~N}$ in with respect to its rabbit host.

Qualitative examination of Fig. 1 (and Table 1) reveals that different species of copepod parasite may exhibit very different isotopic signatures, even on the same host. It would appear, for example, that Clavella adunca are typically depleted in ${ }^{15} \mathrm{~N}$ with respect to their host (cod and whiting) but that adult Lernaeocera branchialis can be either slightly depleted (in cod) or enriched (in haddock and whiting). There is an apparent difference in fractionation between larval (copepodid and chalimus) stages of $L$. branchialis, which infest flatfishes (Pinnegar et al. 2001) and adult females of the same species that affect gadoid fishes (Fig. 1). These different life-history stages are thought to feed in very different ways, with the copepodid feeding chiefly on tissues and mucus of the gill epithelia (Sproston 1942), whilst the adult parasite feeds primar- 
a) Gadus morhua

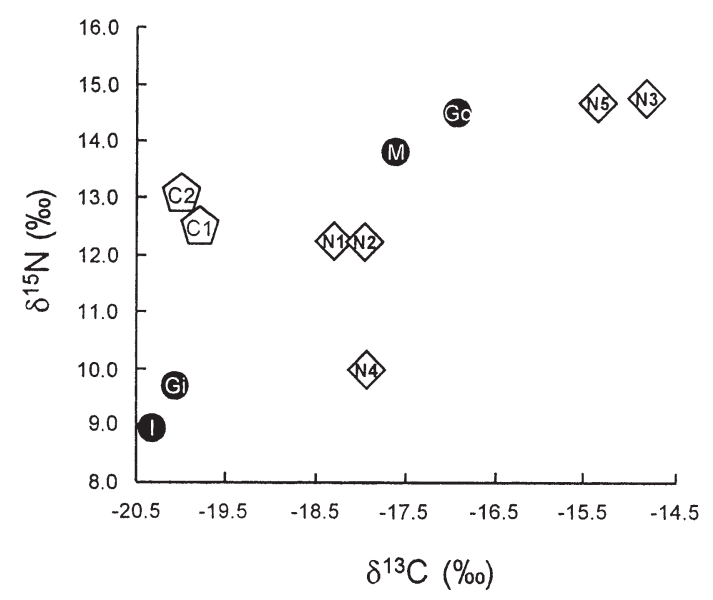

c) Merluccius merluccius

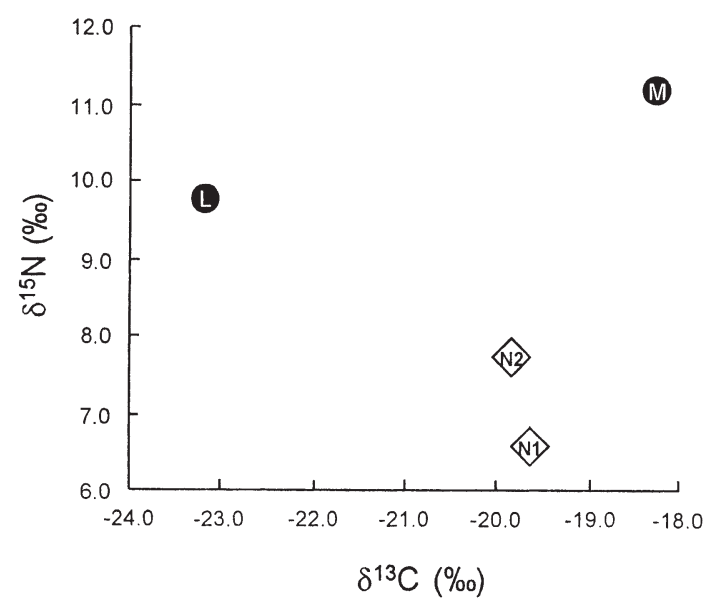

e) Clupea harengus

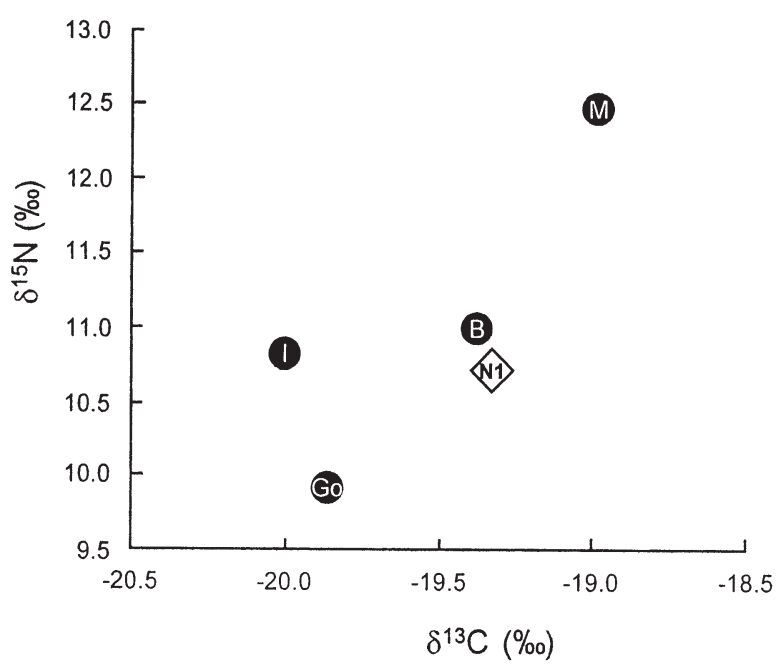

b) Melanogrammus aeglefinus

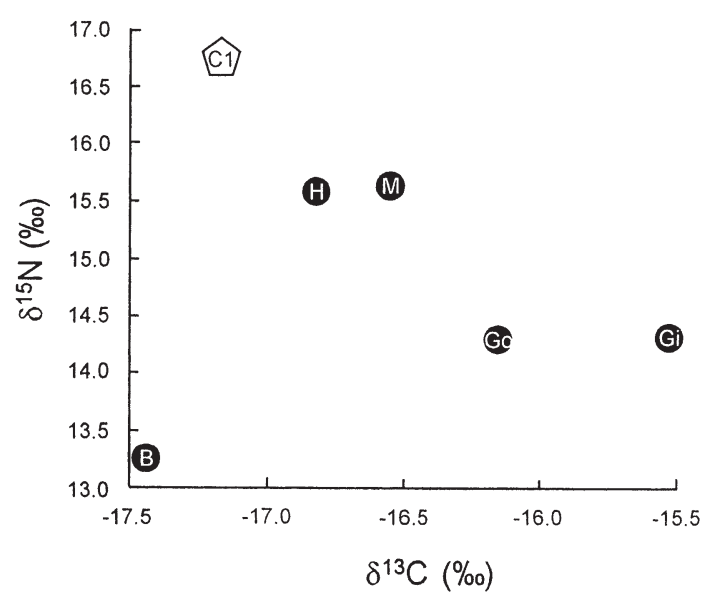

d) Merlangius merlangus

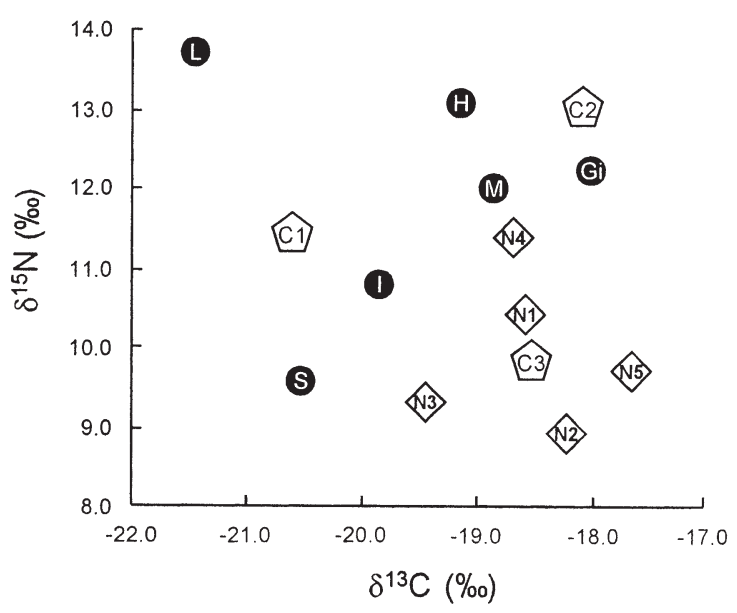

f) Sprattus sprattus

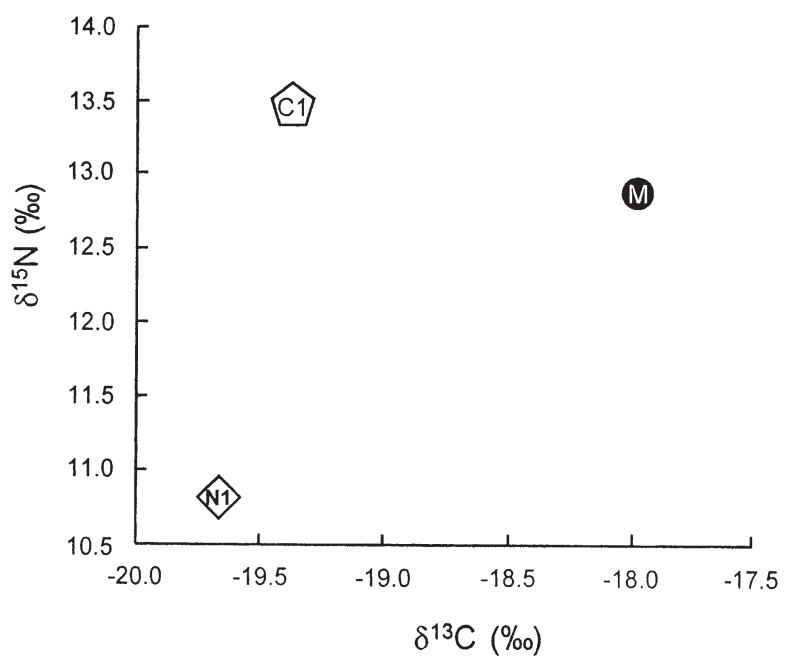

Fig. $1 .{ }^{15} \mathrm{~N}$ and ${ }^{13} \mathrm{C}$ of parasites (open symbols) and body tissues (filled circles) from 10 species of fish host. $\mathrm{M}=\mathrm{muscle}, \mathrm{L}=$ liver, $\mathrm{I}=$ intestine, $\mathrm{Gi}=$ gill filaments, $\mathrm{Go}=$ gonads, $\mathrm{B}=$ blood, $\mathrm{S}=$ stomach. Pentagons $=$ copepods, diamonds $=$ nematodes, square $=$ cestodes (for parasite identifiers see Table 1) 
g) Eutrigla gurnardus

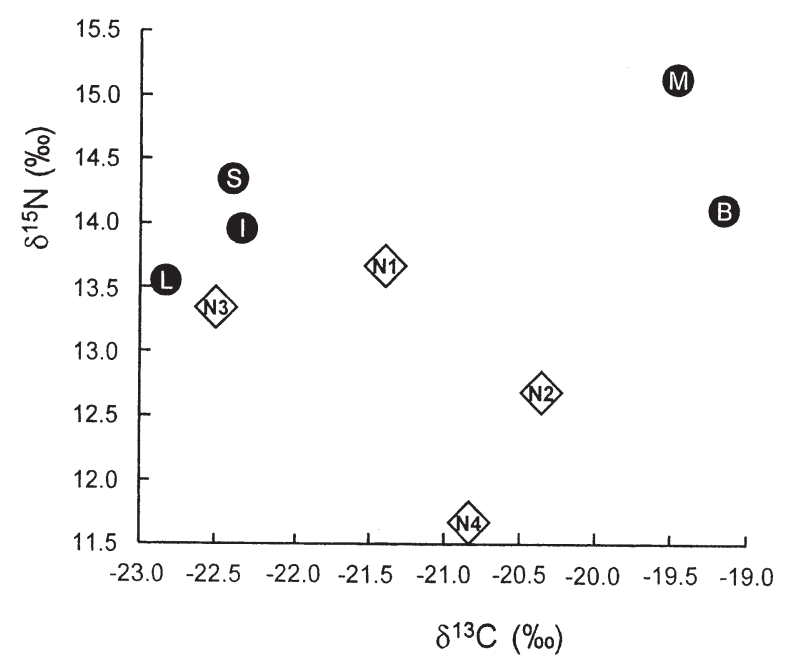

i) Platichthys flesus

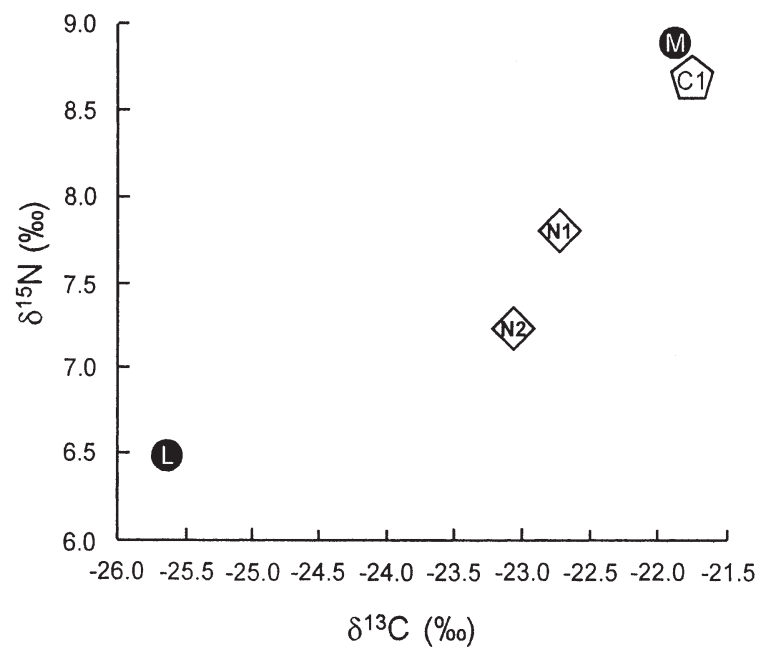

h) Helicolenus dactylopterus

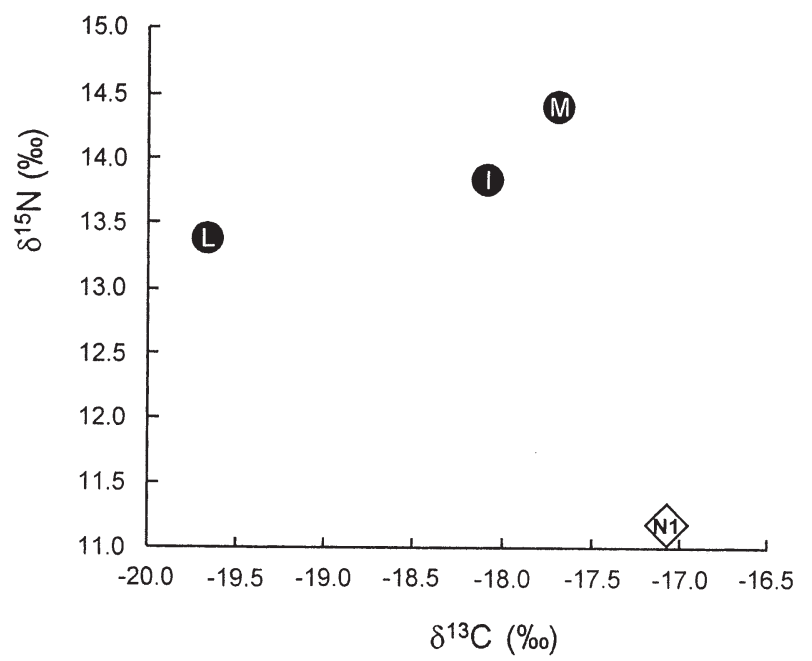

j) Rutilus rutilus

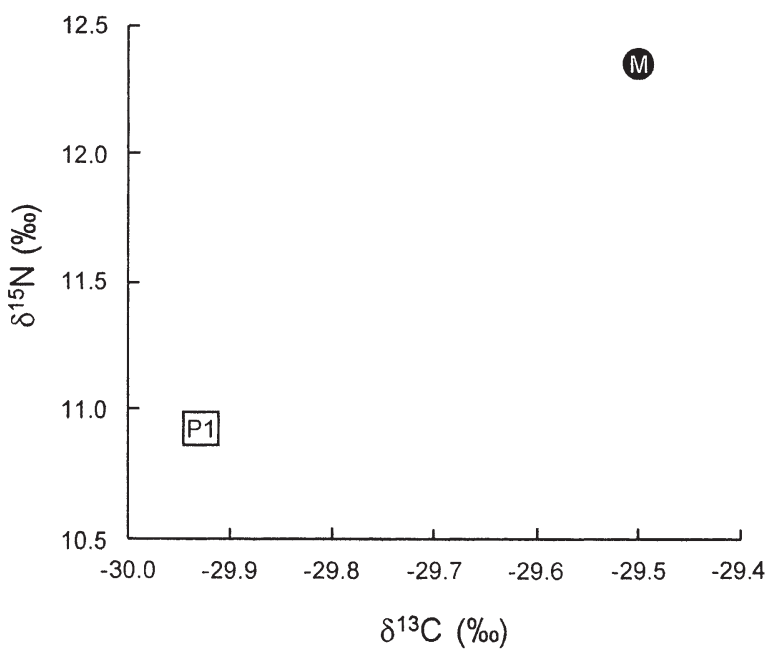

Fig. 1 (continued)

ily on blood from the bulbus arteriosus (Mann 1970). Apparently, the adult parasite does not draw on the blood of the aorta itself but utilises the small vessels surrounding the heart walls. In addition to the host's erythrocytes, cells of the vessel walls have been found in the intestine of adult $L$. branchialis (Mann 1970). $L$. branchialis has been shown to greatly reduce the erythrocyte count and serum haemoglobin content in infected fish (Declerck 1992).

In general 'whole' blood forms an essential part of the diet in most ectoparasites, many of which secrete both haemolytic enzymes and anticoagulant factors to facilitate uptake (e.g. Romestand \& Trilles 1976). Unlike many endoparasitic helminths, ectoparasites cannot simply uptake amino acids across their often heavily keratinised cuticle. Instead they must break down complex blood proteins via transamination, thus explaining why some ectoparasites are enriched in ${ }^{15} \mathrm{~N}$ with respect to their host, as might be expected for a conventional consumer and its diet. In addition, the isotopically 'light' excreta resulting from transamination will be lost to the environment from the parasitehost system and cannot be reutilised by the parasite.

\section{Carbon}

As with ${ }^{15} \mathrm{~N}$, nematodes were consistently depleted in ${ }^{13} \mathrm{C}$ with respect to their hosts, and this is again in clear disagreement with the enrichment pattern (ca. 1\%) conventionally observed between consumers and their diets. Copepod ectoparasites also tended to 
be depleted in ${ }^{13} \mathrm{C}$, and such patterns may be related to the high lipid-content of parasite diets. Presence of the copepod Lernaeocera branchialis has been shown to result in a significant reduction in fat content of infected cod (Khan 1988).

Lipid synthesis discriminates against ${ }^{13} \mathrm{C}$ in favour of the 'lighter' isotope ${ }^{12} \mathrm{C}$ (DeNiro \& Epstein 1977). As a consequence of this, fish tissues which contain large amounts of lipid tend to be depleted with respect to other tissues (Focken \& Becker 1998, Pinnegar \& Polunin 1999). Fish blood and liver possess a relatively high lipid content (Robinson \& Mead 1973, McDonald \& Milligan 1992) and thus these tissues are typically ${ }^{13} \mathrm{C}$ depleted with respect to white muscle (e.g. Pinnegar \& Polunin 1999, Pinnegar et al. 2001). Parasites feeding on these lipid-rich tissues might be expected to be depleted in ${ }^{13} \mathrm{C}$ as a consequence.

Most endoparasites are apparently incapable of synthesising long-chain fatty acids de novo (Köhler \& Voigt 1988), and many parasitic organisms have evolved mechanisms to selectively absorb lipids directly from the host. Fatty acids which are absorbed by parasites are rapidly incorporated into triacyglycerols and phospholipids (Köhler \& Voigt 1988) and research has revealed that anchovy Engraulis encrasicholus infected with larval Hysterothylacium aduncum typically exhibit a decrease in total lipids, particularly triglycerides and non-esterified fatty acids (Shchepkina 1978, 1980). Similarly, gadoid livers infected with $H$. aduncum often show signs of hyperanaemia and their fat content may drop from around $57 \%$ in uninfected fish to $14 \%$ in severely affected fish (Margolis 1970).

In cestodes there is often close correspondence between the fatty acid composition of the parasite and its surroundings (Barrett 1981), and lipids can account for $20 \%$ of the dry weight in larvae and $35 \%$ in adult worms (Köhler \& Voigt 1988). By contrast there is usually little correlation between the fatty-acid composition of nematodes and that of the host tissue (Barrett 1981). This might explain why we found relatively large differences in ${ }^{13} \mathrm{C}$ between many nematodes and their hosts, but no significant difference between the cestode Ligula intestinalis and its host Rutilus rutilus. Similarly, Pinnegar et al. (2001) did not find a significant difference between the ${ }^{13} \mathrm{C}$ of the cestode Schistocephalus solidus and its host Gasterosteus aculeatus.

\section{Parasite site and host specificity}

The very selective feeding of endoparasites on certain biochemicals rather than on bulk tissues of the host might explain the apparent lack of concordance in isotopic signature that we observed between parasites and the tissue with which they were found most closely associated. There are however many other possible explanations for this phenomenon, including migration of the parasite among different tissues within the host's body, changes in the metabolism of the parasite associated with life history, migration between different host animals and changes in the biochemistry, habitat or feeding of the host.

It is unlikely that the distribution and abundance of tissue constituents will remain constant throughout a fish's life. For example lipid-rich vitellogenins in female animals are synthesised in large quantities in the liver at maturity and transported via the bloodstream to the ovary (Norberg \& Haux 1985). Thus ${ }^{13} \mathrm{C}$ will vary greatly among tissues depending on the fish's age and life history. The ${ }^{13} \mathrm{C}$ of parasites feeding on these different fish tissues might be expected to change over time as a consequence of this. Similarly, proteins are broken down and amino acids may be mobilised during periods of nutritional stress; thus, changes in the ${ }^{15} \mathrm{~N}$ of both the host and any parasites might be expected over time (Adams \& Sterner 2000). Nematodes and cestodes which exist as larvae in fish hosts are thought to have a life span of several years, with their consequent accumulation in the fish over time. On the other hand, most nematodes which persist in fish as adults are thought to have shorter life spans, probably <1 yr (Margolis 1970).

Adult and juvenile parasites of the same species, can possess very different abilities to uptake nutrients from their surroundings. For example adult nematodes often possess heavily keratinised cuticles which are apparently impermeable to most molecules including lipids and amino acids (Arme 1976). This may affect the ability of adult parasitic nematodes to feed as selectively as larval forms, since all food must enter the parasite via its digestive tract rather than some materials being absorbed directly across the body surface.

The majority of nematodes (in terms of number of individuals) which infect fishes occur as larvae (i.e. the fishes are only intermediate hosts), and burrow through the gut wall to reach the bloodstream, peritonial cavity or other body organs (Margolis 1970). However, many species which reach sexual maturity in fish hosts (i.e. the fishes are definitive hosts) exist, and these generally occur in the digestive tract (e.g. Ascarophis morrhuae in cod). Adult nematodes, appear to do less damage to the host than do larvae (Sindermann 1990) and are typically concentrated in the hind-gut, large intestine or pyloric caeca. By the time the food reaches these areas it has been at least partially digested and it is therefore in a form which is relatively easy for the parasite to utilise. If we assume that the host's diet was ca. $3 \%$ depleted in ${ }^{15} \mathrm{~N}$ and ca. $1 \%$ depleted in ${ }^{13} \mathrm{C}$ with respect to white muscle, then the stomach nematodes we examined (Fig. 1, Table 1) did not seem to reflect the 
host's diet (gurnard, cod, whiting). In cod, whiting and gurnard, nematodes found in the intestine were highly depleted in both ${ }^{13} \mathrm{C}$ and ${ }^{15} \mathrm{~N}$. We would have expected the parasite to have exhibited ${ }^{13} \mathrm{C}$ and ${ }^{15} \mathrm{~N}$ values indistinguishable from those of the host. Iken et al. (2001) found that trematodes feeding in the intestine of the fish Chalinura profundicola and C. leptolepis did possess very similar ${ }^{15} \mathrm{~N}$ values to their hosts, as did an ectoparasitic gastropod feeding from the gut of the holothurian Oneirophanta mutabilis. However, due to variability in the diet of fish hosts (in time and in space), the isotopic signature of gut parasites is likely to be very variable. Some nematodes are known to be able to use their plate-like jaws to tear the linings of the gut, releasing blood corpuscles on which they feed (Barnes et al. 1988).

Many of the parasites studied here are known to inhabit multiple hosts over the course of their lives. In most, the fish is the second host to be infected. For example Ligula intestinalis initially inhabits copepods, before being passed on to fishes and subsequently to fish-eating birds (the definitive host). Similarly, the life cycle of many nematodes involves a crustacean as first intermediate host, a fish as second intermediate host, and a piscivorous fish, bird or marine mammal as the definitive host (Margolis 1970). Most representatives of the nematode super-families Spiruroidea, Camallanoidea and Dracunculoidea have a 2-host cycle, again infesting an arthropod as the first host, but the fish is the definitive host. Clearly, it is possible that the isotopic signature we observed for each parasite might actually be reflecting that of a previous host. However, the consistent and repeatable fractionation patterns, particularly among nematodes and cestodes, suggest that this was not the case. Were this true, all endoparasite species and all 61 nematode replicates would have had to have switched from a host depleted in ${ }^{15} \mathrm{~N}$ to a host enriched in ${ }^{15} \mathrm{~N}$. Furthermore, the most rapid period of growth (and thus nutrient uptake) in the life cycle of parasites occurs in the plerocercoid (cestodes) or L3 stage (nematodes), i.e. the stage existing within the fish host (Bush et al. 2001). Such parasites only attain the size sampled after being established for some time.

Most parasitic copepods require only 1 host to complete their life cycle (Bush et al. 2001), although some (e.g. Lepeophtheirus pectoralis) are not permanently attached and are capable of abandoning their host from time to time (Mann 1970). L. branchialis requires 2 hosts, a flatfish and a gadoid fish. Once established in the branchial chamber of the gadoid however, the parasite undergoes remarkable morphological modification, and only after a substantial time feeding on the new host attains the large size of those sampled in the present study (Mann 1970).

\section{Conclusions}

The unusual fractionation patterns observed earlier for fish host-parasite systems by Pinnegar et al. (2001) and Iken et al. (2001) seem to apply generally, across a wide range of parasites and hosts. Nematodes were consistently depleted in both ${ }^{15} \mathrm{~N}$ and ${ }^{13} \mathrm{C}$, whilst the few cestodes examined were again depleted in ${ }^{15} \mathrm{~N}$ with respect to their host Rutilus rutilus. Less consistent patterns were observed in ${ }^{15} \mathrm{~N}$ among ectoparasites, and some copepods were enriched in ${ }^{15} \mathrm{~N}$ whilst others were depleted. Most copepods were, however, depleted in ${ }^{13} \mathrm{C}$, and such consistent patterns can provide useful insights into the biochemistry behind parasite-host feeding relationships.

Acknowledgements. The authors would like to thank Daniel Bastreri (Environmental Agency), Beatriz Morales-Nin (IMEDEA-CSIC/UIB), the crew of RV 'Bernicia', David Hoole and Vicky Carter (University of Keele) for helping to obtain additional materials, and assistance in the field. All isotope analyses were conducted by Gillian Taylor at the Biomedical Mass Spectrometry Unit, Newcastle University, UK. This research was funded by the Faculty of Agriculture and Biological Sciences, University of Newcastle, and S.D. was supported by a research grant from the Spanish Ministry of Education.

\section{LITERATURE CITED}

Adams TS, Sterner RW (2000) The effect of dietary nitrogen content on trophic level ${ }^{15} \mathrm{~N}$ enrichment. Limnol Oceanogr 45:601-607

Arme C (1976) Feeding. In: Kennedy CR (ed) Ecological aspects of parasitology. North Holland Publishing Company, Amsterdam, p 75-97

Barnes RSK, Calow P, Olive, PJW (1988) The invertebrates: a new synthesis. Blackwell Scientific Publications, Oxford

Barrett J (1981) Biochemistry of parasitic helminths. Macmillan, London

Boag B, Neilson R, Robinson D, Scrimgeour CM, Handley LL (1998) Wild rabbit host and some parasites show trophiclevel relationships for ${ }^{13} \mathrm{C}$ and ${ }^{15} \mathrm{~N}$ : a first report. Isot Environ Health Stud 34:81-85

Bunn SE, Loneragan NR, Kempster MA (1995) Effects of acid washing on stable isotope ratios of $\mathrm{C}$ and $\mathrm{N}$ in penaeid shrimp and seagrass: implication for food web studies using multiple stable isotopes. Limnol Oceanogr 40: $622-625$

Bush AO, Fernández JC, Esch GW, Seed JR (2001) Parasitism: the diversity and ecology of animal parasites. Cambridge University Press, Cambridge

Declerck D (1992) Occurrence of Lernaeocera branchialis on whiting (Merlangius merlangus) on the Belgian Continental Plate and the Southern North-Sea. Landbouwtijd-Rev Agr 45:1231-1240

DeNiro MJ, Epstein S (1977) Mechanism of stable isotope fractionation associated with lipid synthesis. Science 197: 261-263

DeNiro MJ, Epstein S (1978) Influence of diet on the distribution of carbon isotopes in animals. Geochim Cosmochim Acta 42:495-506 
Doucett RR, Giberson DJ, Power G (1999) Parasitic association of Nanocladius (Diptera: Chironomidae) and Pteronarcys biloba (Plecoptera: Pteronarcyidae): insights from stable-isotope analysis. J North Am Benthol Soc 18: 514-523

Focken U, Becker K (1998) Metabolic fractionation of stable carbon isotopes: implications of different proximate compositions for studies of aquatic food webs using ${ }^{13} \mathrm{C}$ data. Oecologia 115:337-343

Hare PE, Fogel ML, Stafford TW, Mitchell AD, Hoering TC (1991) The isotopic composition of carbon and nitrogen in individual amino acids isolated from modern and fossil proteins. J Archeol Sci 18:277-292

Hesslein RH, Hallard KA, Ramal P (1993) Replacement of sulphur, carbon and nitrogen of growing broad whitefish (Coregonus nasus) in response to a change in diet traced by ${ }^{13} \mathrm{C},{ }^{15} \mathrm{~N}$ and ${ }^{34} \mathrm{~S}$. Can J Fish Aquat Sci $50: 2071-2076$

Howell MJ (1976) The peritoneal cavity of vertebrates. In: Kennedy CR (ed) Ecological aspects of parasitology. North Holland Publishing, Amsterdam, p 243-260

Huxham M, Raffaelli D (1995) Parasites and food-web patterns. J Anim Ecol 64:168-176

Iken K, Brey T, Wand U, Voigt J, Junghans P (2001) Food web structure of the benthic community at Porcupine Abyssal Plain (NE Atlantic): a stable isotope analysis. Prog Oceanogr 50:383-405

Köhler P, Voigt WP (1988) Nutrition and metabolism. In: Mehlhorn H (ed) Parasitology in focus: facts and trends. Springer-Verlag, Berlin, p 412-453

Khan RA (1988) Experimental transmission, development and effects of a parasitic copepod, Lernaeocera branchialis, on Atlantic cod, Gadus morhua. J Parasitol 74:586-599

Macko SA, Estep MF, Engel MH, Hare PE (1986) Kinetic fractionation of stable nitrogen isotopes during amino acid transamination. Geochim Cosmochim Acta 50: $2143-2146$

Mann H (1970) Copepoda and Isopoda as parasites of marine fishes. In: Snieszko SF (ed) A symposium on diseases of fishes and shellfishes. American Fisheries Society Special Publication No. 5, Washington, p 177-189

Marcogliese DJ, Cone DK (1997) Food webs: a plea for parasites. Trends Ecol Evol 12:320-325

Margolis L (1970) Nematode diseases of marine fish. In: Snieszko SF (ed) A symposium on diseases of fishes and shellfishes. American Fisheries Society Special Publication No. 5, Washington, p 190-208

McDonald DG, Milligan CL (1992) Chemical properties of blood. In: Hoar S, Randall DJ, Farrell AD (eds) Fish physiology, Vol XIIB. Academic Press, New York, p 97-105

McLaughlin RL, Kramer DL (1991) The association between amount of red muscle and mobility in fishes: a statistical evaluation. Environ Biol Fish 30:369-378

Minagawa M, Wada E (1984) Stepwise enrichment of ${ }^{15} \mathrm{~N}$ along food chains: further evidence and the relation between ${ }^{15} \mathrm{~N}$ and animal age. Geochim Cosmochim Acta 48:1135-1140

Minchella DJ, Scott ME (1991) Parasitism: a cryptic determinant of animal community structure. Trends Ecol Evol 6: $250-254$

Neilson R, Brown DJF (1999) Feeding on different host plants alters the natural abundances of ${ }^{13} \mathrm{C}$ and ${ }^{15} \mathrm{~N}$ in Longidoridae (nemata). J Nematol 31:20-26

Norberg B, Haux C (1985) Induction, isolation and characterisation of the lipid content of plasma vitellogenin from two Salmo species: rainbow trout (Salmo gairdneri) and sea trout (Salmo trutta). Comp Biochem Physiol 81B:869-876

Olive PJW, Pinnegar JK, Welch R, Richards G, Polunin NVC (in press) Isotope trophic-step fractionation: a dynamic equilibrium model. J Anim Ecol

Pinnegar JK, Polunin NVC (1999) Differential fractionation of ${ }^{13} \mathrm{C}$ and ${ }^{15} \mathrm{~N}$ among fish tissues: implications for the study of trophic interactions. Funct Ecol 13:225-231

Pinnegar JK, Campbell N, Polunin NVC (2001) Unusual stable isotope fractionation patterns observed for fish hostparasite trophic relationships. J Fish Biol 59:494-503

Plimmer RHA (1921) Analysis and energy values of foods. HM Stationery Office, London

Polunin NVC, Pinnegar JK (2002) Trophic ecology and the structure of foodwebs. In: Hart PJB, Reynolds JD (eds) The Handbook of Fish Biology and Fisheries, Vol I. Blackwell Science, Oxford, p 301-320

Post DM, Pace ML, Hairston NG (2000) Ecosystem size determines food-chain length in lakes. Nature 405:1047-1049

Preston T (1992) The measurement of stable isotope natural abundance variations. Plant Cell Environ 15:1091-1097

Robinson JS, Mead JF (1973) Lipid absorption and deposition in rainbow trout (Salmo gairdnerii). Can J Biochem 51: 1051-1058

Romestand MB, Trilles JP (1976) Production d'une substance anticoagulante par les glandes exocrine cephalothoraciques des isopodes Cymothoidae Meinertia oestroides et Anilocra physodes. CR Acad Sci (Paris) 282:663-665

Rutherford TA, Webster JM, Barlow JS (1977) Physiology of nutrient uptake by the entomophilic nematode Mermis nigrescens (Mermithidae). Can J Zool 55:1773-1781

Shchepkina AM (1978) The effect of Contracaecum aduncum larvae on the lipid composition of Engraulis encrasicholus ponticus. Biol Morya (Kiev) 45:109-112

Shchepkina AM (1980) Lipid composition of the tissues of Engraulis encrasicholus during its annual cycle and in infection with larvae of the nematode Contracaecum aduncum. Ekol Morya 3:33-39

Sindermann CJ (1990) Principle diseases of marine fish and shellfish, Vol 1, 2nd edn. Academic Press, San Diego

Soutter AM, Walkey M, Arme C (1980) Amino acids in the plerocercoid of Ligula intestinalis (Cestoda: Pseudophyllidea) and its fish host, Rutilus rutilus. Z Parasitenkd 63: 151-158

Sproston NG (1942) The developmental stages of Lernaeocera branchialis. J Mar Biol Assoc UK 25:441-466

Vander Zanden MJ, Cabana G, Rasmussen JB (1997) Comparing trophic position of freshwater fish calculated using stable nitrogen isotope ratios $\left({ }^{15} \mathrm{~N}\right)$ and literature dietary data. Can J Fish Aquat Sci 54:1142-1158

Velick SF, Vavra J (1962) Glutamic-oxalacetate transaminase. In: Boyer PD, Lardy H, Myrback K (eds) The enzymes, Vol 6. Academic Press, New York, p 219-246

Williams H, Jones A (1994) Parasitic worms of fish. Taylor \& Francis, London

Wilson RP, Poe WE (1974) Nitrogen metabolism in channel catfish, Ictalurus punctatus. III. Relative pool sizes of free amino acids and related compounds in various tissues of the catfish. Comp Biochem Physiol 48B:545-556

Yamaguti S (1958) Systema Helminthum, Vol. I. The digenetic trematodes of vertebrates. Interscience Publishers, New York

Yamaguti S (1959) Systema Helminthum, Vol. II. The cestodes of vertebrates. Interscience Publishers, New York

Yamaguti S (1961) Systema Helminthum, Vol. III. The nematodes of vertebrates. Interscience Publishers, New York

Yamaguti S (1963) Parasitic Copepoda and Branchiura of fishes. Interscience Publishers, New York

Zar JH (1996) Biostatistical analysis, 3rd edn. Prentice Hall, London 